\title{
Commentary \\ Essential function for ErbB3 in breast cancer proliferation
} Elena Perez-Nadales and Alison C Lloyd

\author{
MRC Laboratory for Molecular Cell Biology, University College London, Gower Street, London, UK \\ Corresponding author: Alison C Lloyd (e-mail: alison.lloyd@ucl.ac.uk) \\ Published: 2 April 2004 \\ Breast Cancer Res 2004, 6:137-139 (DOI 10.1186/bcr792) \\ (C) 2004 BioMed Central Ltd
}

\begin{abstract}
The overexpression of the ErbB family of tyrosine kinase receptors is thought to be important in the development of many breast tumours. To date, most attention has focused on the ErbB2 receptor. Now, in a recent report, it has been shown that ErbB3 is a critical partner for the transforming activity of ErbB2 in breast cancer cells. Importantly, the proliferative signals from this transforming complex appear to act via the PI-3 kinase pathway.
\end{abstract}

Keywords: breast, ErbB2, ErbB3, PI-3K, PKB

A hallmark of cancer cells is that they are able to proliferate in the absence of normal proliferative signals. This self-sufficiency in growth signals is often achieved through genetic changes that result in the overexpression of growth factors or their receptors. In breast epithelial cells, normal proliferation is regulated by both steroid hormone receptors and the ErbB family of peptide growth factor receptors (also called Type I receptor tyrosine kinases or RTKs). Overexpression of these receptors is frequently found in breast cancer, and identification of the molecular pathways involved has permitted the development of new breast cancer therapies.

Most anti-breast cancer drugs under investigation or in current use act to inactivate the oestrogen receptor or the ErbB receptors, ErbB2 and ErbB1. In particular, much research has focused on the ErbB2 oncogene, because this gene is frequently overexpressed in breast tumours and is associated with a poorer prognosis. Now, however, in a recent report, Holbro and colleagues [1] highlight the oncogenic potential of another ErbB receptor, the ErbB3 receptor, by showing that ErbB3 functions as an essential partner of ErbB2 to drive the proliferation of ErbB2overexpressing breast tumour cells.

The ErbB family of receptors form homodimers and heterodimers on ligand binding to the extracellular domain.
The receptor dimer is activated through intrinsic tyrosine kinase-mediated autophosphorylation of the receptors in the cytoplasmic domain. These phosphorylations result in the recruitment of downstream effector proteins that activate multiple signalling pathways including the mitogen-activated protein (MAP) kinase and phosphoinositide 3-kinase (PI-3K) pathways [2-4]. ErbB3 is distinct in that it has an impaired protein tyrosine kinase activity and activation of this receptor is achieved only through the formation of heterodimeric receptor complexes with other kinase-active family members [5-7]. In this way, the ErbB2-ErbB3 complex can act as a high-affinity heregulin co-receptor [8]. The ErbB3 receptor is also unique among the ErbB family in its ability to directly recruit and activate $\mathrm{Pl}-3 \mathrm{~K}[5,9]$.

Elevated levels of tyrosine-phosphorylated ErbB3 are frequently found in breast tumours that overexpress ErbB2 $[10,11]$. In addition, in vitro assays in NIH 3 T3 cells and a transgenic mouse model of breast cancer development have shown that ErbB2 cooperates with ErbB3 to transform cells $[12,13]$. This has led to speculation that ErbB3 might be an important partner to ErbB2 in the development of breast tumours overexpressing ErbB2. To address this issue definitively, Holbro and colleagues used elegant techniques to disrupt ErbB3 and ErbB2 function selectively in breast cancer cells. They blocked ErbB2 
activity by using either the ErbB2-selective kinase inhibitor PKI166 [14] or by functionally inactivating the receptor through expression of the single-chain antibody scFv-5R, which targets ErbB2 to the endoplasmic reticulum [15]. To inhibit ErbB3 expression, they infected the cells retrovirally with an artificial transcription factor, E3, composed of a polydactyl zinc-finger domain, which specifically recognizes the $5^{\prime}$ untranslated region of c-erbB3 and downregulates its expression [16].

With these techniques they demonstrated that ErbB2 inactivation blocked proliferation in ErbB2-overexpressing cells and that this was associated with a decrease in the phosphotyrosine content of ErbB3, confirming that ErbB2 activity was required to activate ErbB3. Inactivation of ErbB2 was also associated with a decrease in the level of ErbB3-PI-3K complex and the activity of the PI-3K target, protein kinase $B(P K B)$, demonstrating that activation of the PI-3K pathway was downstream of this receptor. Importantly, they found that specific downregulation of the ErbB3 receptor, using the E3 transcription factor, had similar antiproliferative effects on the cell lines overexpressing ErbB2. The specificity of this effect was confirmed by re-expressing ectopic ErbB3 under the control of a promoter that was insensitive to the E3 transcription factor. Interestingly, some of the cell lines tested also express ErbB1 and ErbB4, suggesting that neither of these receptors is able to substitute for ErbB3. This idea was confirmed by the observation that reexpression of ErbB4 was unable to rescue loss of ErbB3. Together, these results clearly show that ErbB3 is required for ErbB2 to be transforming in these cells.

Looking at downstream signalling pathways, the authors observed that, although loss of ErbB3 had no effect on the levels of signalling through the MAP kinase pathway, signalling through the PI-3K pathway was blocked in one cell line. This result suggested that the proliferative signal from this receptor complex was transmitted via this pathway. This finding was corroborated by the observation that constitutive activation of this pathway by the expression of an active form of PKB was sufficient to overcome the proliferative arrest seen in response to the loss of either receptor. Thus, the ErbB2-ErbB3 complex stimulates an oncogenic, proliferative signal via the PI-3K pathway.

The clear demonstration of the requirement of ErbB3 as a partner for ErbB2 in breast cell transformation and the observation that the proliferative drive requires signalling through the PI-3K pathway are in line with previous findings. Using a dominant-negative version of ErbB3, Ram and colleagues reported similar findings that ErbB3 function seemed to be required for the growth factor and anchorage independence of an ErbB2-overexpressing breast cancer cell line [17]. In addition, mutagenesis of the ability of the ErbB2-ErbB3 complex in NIH 3T3 cells points to the importance of the PI-3K pathway in the induction of cellular transformation [18].

The importance of the PI-3K pathway in breast cancer is also suggested by the finding of PTEN deletions and overexpression of PKB in primary breast tumours $[19,20]$. How does this pathway lead to deregulation of the cell cycle? Holbro and colleagues show that inactivation of this pathway is correlated with a loss of cyclin D3 expression and with a decrease in the phosphorylation of retinoblastoma protein. $\mathrm{PI}-3 \mathrm{~K}$ signalling is known to regulate cyclin $D$ levels at both the transcriptional and translational levels [21] and is also known to regulate the concentrations and localization of the cyclin-dependent kinase inhibitor p27 ${ }^{K i p 1}$ [22]. It will be of interest to see whether these are the signalling pathways responsible for driving the proliferation of these cells in this context.

These studies clearly show an important role for the PI-3K pathway in the ability of the ErbB2-ErbB3 complex to drive proliferation. However, other signalling pathways originating from the ErbB2-ErbB3 oncogenic unit undoubtedly contribute to transformation in vivo. The ErbB2-ErbB3 heterodimer has been reported to increase cell motility and to induce morphological changes that seem to require both $\mathrm{PI}-3 \mathrm{~K}$ and MAP kinase signalling [23]. In addition, the ErbB2-ErbB3 heterodimer has been reported to upregulate matrix metalloproteinase-9 expression, which is thought to be important in promoting tumour invasiveness and metastasis [24]. MAP kinase, p38, protein kinase $\mathrm{C}$ and $\mathrm{PI}-3 \mathrm{~K}$ signalling pathways all seem to have a role in this process. In addition, Src family signalling is thought to be important in the transformation process downstream of ErbB2, through regulation of the cytoskeletal changes that accompany malignant transformation [25].

These findings are relevant to a large proportion of breast malignancies but might also be useful for our understanding of other malignancies. In colorectal cancer, an increase in ErbB2 expression is often associated with an increase in ErbB3 expression [26]. Moreover, co-expression of ErbB2 and ErbB3 is also found in oral squamous cell carcinoma, ovarian tumours and lung adenocarcinomas and in many cases seems to be important for the transformed phenotype of the tumour $[27,28]$.

Advances in our understanding of the molecular pathways responsible for ErbB-mediated transformation should result in the development of novel strategies for treating breast cancer. In particular, the demonstration of an important role of ErbB3 and the PI-3K pathway in driving the proliferation of ErbB2-overexpressing breast cancer cells makes them attractive targets for anti-breast cancer drugs for this subset of patients. One such drug currently 
undergoing trials is the monoclonal antibody $2 \mathrm{C} 4$, which can disrupt the process of heterodimerisation of the ErbB2-ErbB3 receptor by hindering the recruitment of ErbB2 into ErbB3 complexes [29]. It is to be hoped that the identification of ErbB3 as a requisite component of ErbB2 signalling will result in the development of further promising new drugs.

\section{Competing interests}

None declared.

\section{References}

1. Holbro T, Beerli RR, Maurer F, Koziczak M, Barbas CF 3rd, Hynes NE: The ErbB2/ErbB3 heterodimer functions as an oncogenic unit: ErbB2 requires ErbB3 to drive breast tumor cell proliferation. Proc Natl Acad Sci USA 2003, 100:8933-8938.

2. Riese DJ 2nd, Stern DF: Specificity within the EGF family/ErbB receptor family signaling network. BioEssays 1998, 20:41-48.

3. Yarden $\mathrm{Y}$, Sliwkowski MX: Untangling the ErbB signalling network. Nat Rev Mol Cell Biol 2001, 2:127-137.

4. Olayioye MA, Neve RM, Lane HA, Hynes NE: The ErbB signaling network: receptor heterodimerization in development and cancer. EMBO J 2000, 19:3159-3167.

5. Carraway KL 3rd, Cantley LC: A neu acquaintance for erbB3 and erbB4: a role for receptor heterodimerization in growth signaling. Cell 1994, 78:5-8

6. Pinkas-Kramarski R, Shelly M, Glathe S, Ratzkin BJ, Yarden Y: Neu differentiation factor/neuregulin isoforms activate distinct receptor combinations. J Biol Chem 1996, 271:1902919032.

7. Guy PM, Platko JV, Cantley LC, Cerione RA, Carraway KL 3rd: Insect cell-expressed p180erbB3 possesses an impaired tyrosine kinase activity. Proc Natl Acad Sci USA 1994, 91: 8132-8136.

8. Fitzpatrick VD, Pisacane PI, Vandlen RL, Sliwkowski MX: Formation of a high affinity heregulin binding site using the soluble extracellular domains of ErbB2 with ErbB3 or ErbB4. FEBS Lett 1998, 431:102-106.

9. Fedi P, Pierce JH, di Fiore PP, Kraus MH: Efficient coupling with phosphatidylinositol 3-kinase, but not phospholipase C gamma or GTPase-activating protein, distinguishes ErbB-3 signaling from that of other ErbB/EGFR family members. Mol Cell Biol 1994, 14:492-500.

10. Naidu R, Yadav M, Nair S, Kutty MK: Expression of c-erbB3 protein in primary breast carcinomas. $\mathrm{Br} J$ Cancer 1998, 78: 1385-1390.

11. Lemoine NR, Barnes DM, Hollywood DP, Hughes CM, Smith P, Dublin E, Prigent SA, Gullick WJ, Hurst HC: Expression of the ERBB3 gene product in breast cancer. $\mathrm{Br} J$ Cancer 1992, 66: 1116-1121.

12. Alimandi $M$, Romano $A$, Curia $M C$, Muraro R, Fedi $P$, Aaronson SA, Di Fiore PP, Kraus MH: Cooperative signaling of ErbB3 and ErbB2 in neoplastic transformation and human mammary carcinomas. Oncogene 1995, 10:1813-1821.

13. Siegel PM, Ryan ED, Cardiff RD, Muller WJ: Elevated expression of activated forms of Neu/ErbB-2 and ErbB-3 are involved in the induction of mammary tumors in transgenic mice: implications for human breast cancer. EMBO J 1999, 18:2149-2164.

14. Traxler $P$, Bold G, Buchdunger E, Caravatti G, Furet $P$, Manley $P$, O'Reilly T, Wood J, Zimmermann J: Tyrosine kinase inhibitors: from rational design to clinical trials. Med Res Rev 2001, 21: 499-512.

15. Beerli RR, Wels W, Hynes NE: Inhibition of signaling from Type 1 receptor tyrosine kinases via intracellular expression of single-chain antibodies. Breast Cancer Res Treat 1996, 38:1117.

16. Beerli RR, Schopfer U, Dreier B, Barbas CF 3rd: Chemically regulated zinc finger transcription factors. J Biol Chem 2000, 275: 32617-32627.

17. Ram TG, Schelling ME, Hosick HL: Blocking HER-2/HER-3 function with a dominant negative form of HER-3 in cells stimulated by heregulin and in breast cancer cells with HER-2 gene amplification. Cell Growth Differ 2000, 11:173-183.
18. Vijapurkar U, Kim MS, Koland JG: Roles of mitogen-activated protein kinase and phosphoinositide $3^{\prime}$-kinase in ErbB2/ ErbB3 coreceptor-mediated heregulin signaling. Exp Cell Res 2003, 284:291-302.

19. Mills GB, Lu Y, Fang X, Wang H, Eder A, Mao M, Swaby R, Cheng KW, Stokoe D, Siminovitch K, Jaffe R, Gray J: The role of genetic abnormalities of PTEN and the phosphatidylinositol 3kinase pathway in breast and ovarian tumorigenesis, prognosis, and therapy. Semin Oncol 2001, 28:125-141.

20. Hill MM, Hemmings BA: Inhibition of protein kinase B/Akt implications for cancer therapy. Pharmacol Ther 2002, 93:243251.

21. Basso $A D$, Solit DB, Munster PN, Rosen N: Ansamycin antibiotics inhibit Akt activation and cyclin $D$ expression in breast cancer cells that overexpress HER2. Oncogene 2002, 21: 1159-1166.

22. Alkarain A, Slingerland J: Deregulation of p27 by oncogenic signaling and its prognostic significance in breast cancer. Breast Cancer Res 2004, 6:13-21.

23. Chausovsky A, Waterman H, Elbaum M, Yarden Y, Geiger B, Bershadsky AD: Molecular requirements for the effect of neuregulin on cell spreading, motility and colony organization. Oncogene 2000, 19:878-888.

24. Xu FJ, Stack S, Boyer C, O'Briant K, Whitaker R, Mills GB, Yu YH, Bast RC Jr: Heregulin and agonistic anti-p185(c-erbB2) antibodies inhibit proliferation but increase invasiveness of breast cancer cells that overexpress p185(c-erbB2): increased invasiveness may contribute to poor prognosis. Clin Cancer Res 1997, 3:1629-1634.

25. Vadlamudi RK, Sahin AA, Adam L, Wang RA, Kumar R: Heregulin and HER2 signaling selectively activates c-Src phosphorylation at tyrosine 215. FEBS Lett 2003, 543:76-80.

26. Maurer CA, Friess H, Kretschmann B, Zimmermann A, Stauffer A, Baer HU, Korc M, Buchler MW: Increased expression of erbB3 in colorectal cancer is associated with concomitant increase in the level of erbB2. Hum Pathol 1998, 29:771-777.

27. Sithanandam G, Smith GT, Masuda A, Takahashi T, Anderson LM, Fornwald LW: Cell cycle activation in lung adenocarcinoma cells by the ErbB3/phosphatidylinositol 3-kinase/Akt pathway. Carcinogenesis 2003, 24:1581-1592.

28. Xia W, Lau YK, Zhang HZ, Xiao FY, Johnston DA, Liu AR, Li L, Katz RL, Hung MC: Combination of EGFR, HER-2/neu, and HER-3 is a stronger predictor for the outcome of oral squamous cell carcinoma than any individual family members. Clin Cancer Res 1999, 5:4164-4174.

29. Agus DB, Akita RW, Fox WD, Lewis GD, Higgins B, Pisacane PI, Lofgren JA, Tindell C, Evans DP, Maiese K, Scher HI, Sliwkowski MX: Targeting ligand-activated ErbB2 signaling inhibits breast and prostate tumor growth. Cancer Cell 2002, 2:127-137.

\section{Correspondence}

Alison C Lloyd, MRC Laboratory for Molecular Cell Biology, University College London, Gower Street, London WC1E 6BT, UK. Tel: +44 207 679 2240; fax: +44 207679 7805; e-mail: alison.lloyd@ucl.ac.uk 